\title{
Article \\ Application of Untargeted Metabolomics to Determine Volatile Compounds from the Spanish Plant Arctostaphylos uva-ursi Used as Tea
}

\author{
Magdalena Wrona ${ }^{1}$, Davinson Pezo ${ }^{2}$ (D), Maria Anna Rovito ${ }^{3}$, Paula Vera ${ }^{1}$, Cristina Nerín ${ }^{1}$ (I) \\ and Esther Asensio 1,*(D) \\ 1 Department of Analytical Chemistry, Aragon Institute of Engineering Research I3A, \\ CPS-University of Zaragoza, Torres Quevedo Building, María de Luna Str. 3, 50018 Zaragoza, Spain; \\ magdalena.wrona@unizar.es (M.W.); pvera@unizar.es (P.V.); cnerin@unizar.es (C.N.) \\ 2 Faculty of Health Sciences, San Jorge University, Autovía A-23 Zaragoza-Huesca Km. 299, \\ 50830 Villanueva de Gallego, Spain; dpezo@usj.es \\ 3 School of Agricultural, Forestry, Food and Environmental Sciences, University of Basilicata, \\ Viale dell'Ateneo Lucano 10, 85100 Potenza, Italy; mariaanna.rovito@gmail.com \\ * Correspondence: estherac@unizar.es; Tel.: +34-876-555-279
}

check for updates

Citation: Wrona, M.; Pezo, D.; Rovito, M.A.; Vera, P.; Nerín, C.; Asensio, E. Application of Untargeted Metabolomics to Determine Volatile Compounds from the Spanish Plant Arctostaphylos uva-ursi Used as Tea. Separations 2022, 9, 68. https:// doi.org/10.3390/separations 9030068 Academic Editors: Natalia Drabińska and Marta Ferreiro-González

Received: 6 February 2022

Accepted: 1 March 2022

Published: 4 March 2022

Publisher's Note: MDPI stays neutral with regard to jurisdictional claims in published maps and institutional affiliations.

Copyright: () 2022 by the authors Licensee MDPI, Basel, Switzerland. This article is an open access article distributed under the terms and conditions of the Creative Commons Attribution (CC BY) license (https:// creativecommons.org/licenses/by/ $4.0 /)$.

\begin{abstract}
One-hundred and seven different volatile compounds were identified in the samples of Arctostaphylos uva-ursi collected from nine locations in Spain. This plant is commonly brewed and used as tea. Volatile compounds profile was detected using solid-phase microextraction gas chromatographymass spectrometry. The most interesting compounds detected from an antioxidant capacity point of view were esters, phenols, and aromatics compounds. All samples were discriminated by principal component analysis. The insolation and altitude of harvest areas, and latent structures were considered for interpretation of results. Discriminant analysis was applied to control the type and concentration of metabolites and determine the best plant antioxidant profiles of volatile compounds from plant origin. Moreover, a heatmap displayed correlations between detected compounds. The discriminant analysis led to 20 quality markers being identified for the analysed plants. The strongest antioxidant capacity was obtained in the samples from Pina de Montalgrao and Loarre (collected in September) for ORAC ( $33.11 \pm 0.61 \mathrm{~g}$ Trolox $/ \mathrm{g}$ sample) and DPPH ( $\left.\mathrm{IC}_{50}=711 \pm 12 \mu \mathrm{g} / \mathrm{g}\right)$ methods, respectively. The plant with the highest total phenolic content was Loarre collected in September $(171.9 \pm 19.4 \mathrm{mg}$ GAE/g DW) and November (177.1 $\pm 11.0 \mathrm{mg}$ GAE/g DW).
\end{abstract}

Keywords: Arctostaphylos uva-ursi; volatile compounds; untargeted metabolomics

\section{Introduction}

The vast attention has been recently directed towards investigating and isolating natural antioxidants from botanical sources, mostly edible plants [1]. Arctostaphylos uvaursi (A. uva-ursi) is an evergreen plant known as bearberry that occupies a wide variety of habitats in the Iberian Peninsula, North America, Siberia, and Asia [2]. It adapts to both siliceous and limestone soils and covers large land areas, including pine forests. The plant can be brewed and used as $u v a$-ursi tea. It should be highlighted that active agents in Arctostaphylos uva-ursi leaves can be related to geographic conditions influencing the adaptation of this plant into stress [2-4] Therefore, the Spanish variety of Arctostaphylos uva-ursi is an exciting target of investigation because of a possible large diversity of active ingredients present in the plant due to insolation conditions connected with harvest time and geographic location associated with altitude.

The antimicrobial and anti-inflammatory properties of Arctostaphylos uva-ursi leaves have been already widely investigated $[5,6]$, revealing its healing effects $[4,7,8]$. Moreover, the scientific literature already describes some studies of the antioxidant properties of Arctostaphylos uva-ursi [9,10]. 
In medicinal and aromatic plants, their high quality is crucial, ensuring safe consumption and its effectiveness. One of the indicators of medicinal plants quality can be the levels of antioxidants present in them [11].

Antioxidants are substances highly valued by scientists for their role in preventing damage caused by oxidative processes. Thus, these compounds are used in various areas of science and industry [12-16]. Researchers recently have made efforts to replace synthetic antioxidants with natural ones, as some synthetic antioxidants are considered hazardous [17]. Research into antioxidants from natural sources is essential to improving and bringing the latest advances to the market in the case of pharmaceuticals, dietary supplements, food additives and active packaging.

Antioxidant activity (AOX) is a molecule's ability to bind free radicals. AOX can be applied as parameters characterizing pure chemical compounds, complex extracts, and essential oils. AOX is related to the presence of compounds capable of protecting a biological system against harmful oxidation. Therefore, plants are a great source of natural antioxidants [18]. It should be highlighted that herbs and teas are safer sources of natural antioxidants, and they have been used for this purpose by human beings for centuries $[19,20]$.

The AOX of each extract of a plant depends on its chemical composition. In addition to polyphenols and other non-volatile substances [21,22], volatile compounds can play an important role in the AOX of a sample.

Analysis of volatile compounds is commonly performed by gas chromatographymass spectrometry (GC-MS) or solid-phase microextraction gas chromatography-mass spectrometry (SPME-GC-MS) which are sensitive analytical techniques able to perform trace analysis. The advantage of hyphenated gas chromatography is the coupling of automated sample preparation techniques with GC and MS detector. It turns it into a versatile tool for quick untargeted metabolomics of a considerable number of samples. Plant metabolomics allows a complete analysis of the chemical compounds present in samples from different locations and harvest conditions, as well as the identification of their quality markers.

The untargeted metabolomics should be applied to investigate the volatile compounds profile of plant extracts from various geographical locations, as in this case, specific analytes are unknown. Undoubtedly, untargeted metabolomics and data handling are difficult and complex, and data fusion and multivariate analysis are needed to facilitate the work.

The conducted research aimed to create a modern procedure for determining quality markers for the Arctostaphylos uva-ursi plant collected from various Spanish locations. The hyphenated gas chromatography technique headspace-gas chromatography-mass spectrometry (HS-SPME-GC-MS) was applied to accomplish this specific objective. As a result, the direct identification of the volatile compounds has been performed. Moreover, chemometric tools were used to investigate the connection between volatile compounds (VOCs) profile, plant origin, and AOX. As a result, antioxidant markers are presented for characterization, authentication, quality, and AOX control of the Arctostaphylos uva-ursi plant within their application in different market sectors. Two different methods for the assessment of AOX have been applied: oxygen radical absorbance capacity (ORAC) and 2,2-diphenyl-1-(2,4,6-trinitrophenyl) hydrazyl (DPPH) assays.

\section{Materials and Methods}

\subsection{Reagents}

2,2-Diphenyl-1-(2,4,6-trinitrophenyl) hydrazyl (DPPH; CAS 1898-664); azobis(2-methylpropionamidine) dihydrochloride (AAPH; 97\%, CAS 2997-92-4); fluorescein (CAS 518-47-8); Trolox (98\%, CAS 53188-07-1); gallic acid (97\%, CAS 149-91-7) and Folin-Ciocalteu phenol reagent $(2 \mathrm{~N})$ were obtained from Sigma Aldrich (Madrid, Spain). Sodium carbonate anhydrous was purchased from Panreac (Barcelona, Spain). Sodium dihydrogen phosphate monohydrate (99\%, CAS 7558-80-7) and disodium hydrogen phosphate dihydrate (99.5\%, CAS 10028-24-7) were from Merck (Madrid, Spain). Methanol LC-MS (CAS 67-56-1) 
was purchased from Honeywell (Barcelona, Spain). An n-alkanes $\left(\mathrm{C}_{7}\right.$ to $\left.\mathrm{C}_{40}\right)$ standard was supplied as a $1000 \mu \mathrm{g} / \mathrm{mL}$ hexane solution (Code No.: 49452-U) by Supelco (Bellefonte, PA, USA). Ultrapure water was obtained from a Wasserlab Ultramatic GR system (Barbatáin, Spain).

\subsection{Samples Treatment}

Nine different samples of Arctostaphylos uva-ursi were analyzed. Confirmation of species was done in the herbarium at the Botanic Institute of Barcelona (BC). Samples were collected from eight different Spain regions to evaluate the effect of geographical location on the leaves composition and AOX. Moreover, the samples were harvested at two times: in September and November 2015, to assess the influence of insolation. The origin of samples, collection times and solar radiation [23] are shown in Table 1. The geographical closeness of harvest areas has been marked with different colours. Additionally the exact locations where the Arctostaphylos uva-ursi samples were collected from different parts of Spain was presented in a contour map of Spain in our previous study [21].

Table 1. Origin of analysed samples.

\begin{tabular}{|c|c|c|c|c|c|}
\hline $\begin{array}{l}\text { Sample } \\
\text { Name }\end{array}$ & Harvest Area & Province & $\begin{array}{l}\text { Altitude } \\
\quad(\mathrm{m})\end{array}$ & $\begin{array}{l}\text { Harvest } \\
\text { Time }\end{array}$ & $\begin{array}{c}\text { Solar Radiation } \\
\left(\mathrm{MJ} / \mathrm{m}^{2}\right)\end{array}$ \\
\hline $\mathrm{AL}$ & Albarracín & Teruel & 1337 & September & 492 \\
\hline $\mathrm{CH}$ & Chelva & Valencia & 984 & September & 484 \\
\hline $\mathrm{HU}$ & Huétor & Granada & 1354 & November & 509 \\
\hline LO_S & Loarre & Huesca & 1401 & September & 491 \\
\hline LO_N & Loarre & Huesca & 1401 & November & 236 \\
\hline$\overline{L I}$ & Lierta & Huesca & 590 & September & 491 \\
\hline PI & $\begin{array}{c}\text { Pina de } \\
\text { Montalgrao }\end{array}$ & Castellón & 1278 & September & 483 \\
\hline $\mathrm{TO}$ & El Toro & Castellón & 999 & September & 483 \\
\hline VE & Los Vélez & Almería & 1369 & September & 536 \\
\hline
\end{tabular}

The 72 leaves mixture (nine leaves from eight different plants) from all collected plants from each geographical location was used as a representative sample. The Arctostaphylos uva-ursi leaves have been dried for one day at $60^{\circ} \mathrm{C}$ and ground. It should be highlighted that the plant samples are usually dried at $60{ }^{\circ} \mathrm{C}$ to preserve them better from water and humidity that cause serious conservation problems. The screw cap vial of the total capacity of $20 \mathrm{~mL}$ was used to place $0.5 \mathrm{~g}$ of sample. Then it was directly analyzed by HS-SPME-GC-MS. All samples were prepared in triplicate.

\subsection{Equipment and GC Conditions}

A Branson 3510 ultrasonic bath (Branson Ultrasonic Corporation, Brookfield, CT, USA) was used for extraction. A UV-1700 spectrophotometer (Shimadzu Pharmaspec Ibérica, Madrid, Spain) was used for the AOX assays.

An Agilent $6890 \mathrm{~N}$ gas chromatograph (CTC Analytics, Palo Alto, CA, USA) equipped with a CombiPal autosampler (CTC Analytics, Zwingen, Switzerland) and a mass spectrometer (MS) detector was used for volatile compounds analysis. An SPME holder (Supelco) was used to perform the extraction of analytes. Also, a blank (empty vial) was analyzed.

The oven temperature was set to $40{ }^{\circ} \mathrm{C}$, and it was maintained for $5 \mathrm{~min}$. It was then raised with a $10^{\circ} \mathrm{C} / \mathrm{min}$ rate to the reach final temperature $\left(220^{\circ} \mathrm{C}\right)$ held for $5 \mathrm{~min}$. Carrier gas (helium) flow was $1 \mathrm{~mL} / \mathrm{min}$. The injector's temperature was $250{ }^{\circ} \mathrm{C}$, and the splitless mode was applied. SCAN mode in the range of $50-350 \mathrm{~m} / \mathrm{z}$ was chosen as acquisition mode.

\subsection{Qualitative Analysis}

Qualitative analysis has been based on comparing the mass spectrum of analytes peaks with the National Institute of Standards and Technology (NIST) library (NIST 14). 
Moreover, Kovats Retention Index (KI) was calculated for each compound by using a $10 \mu \mathrm{g} / \mathrm{g}$ standard mixture of $n$-alkanes $\left(C_{7-} C_{40}\right)$ in hexane. External standards have not been used for qualitative analytes confirmation therefore the component identifications should be considered tentative.

\subsection{Optimisation of HS-SPME-GC-MS Conditions}

Two different columns-HP-5MS (30 $\mathrm{m} \times 0.25 \mathrm{~mm} \times 0.25 \mu \mathrm{m})$ and Carbowax $20 \mathrm{M}$ $(30 \mathrm{~m} \times 0.25 \mathrm{~mm} \times 0.25 \mu \mathrm{m})$ - from Agilent Technologies (Madrid, Spain) were tested for chromatographic separations.

HS-SPME extraction conditions were also optimized. The first step was selecting the most appropriate SPME fibre for each sample. Two fibres with different polarities and thicknesses were tested to cover all ranges of possible analytes: (a) polydimethylsiloxane (PDMS) fibre of $100 \mu \mathrm{m}$ and (b) divinylbenzene/carboxen/polydimethylsiloxane (DVB/CAR/PDMS) fibre of 50/30 $\mu \mathrm{m}$. Both fibres were supplied by Supelco. They were conditioned in the needle heater set at $250{ }^{\circ} \mathrm{C}$ during $30 \mathrm{~min}$ for PDMS fibre and $270{ }^{\circ} \mathrm{C}$ during $30 \mathrm{~min}$ for DVB/CAR/PDMS fibre (parameters specified by the manufacturer). The conditioning process has been performed before first use.

Also, adsorption temperatures $\left(50\right.$ and $80^{\circ} \mathrm{C}$ ), adsorption times (sampling times) (15 and $30 \mathrm{~min}$ ), and desorption times (1 and $2 \mathrm{~min}$ ) were checked. The selection of parameters was based on experience of our research group on VOCs investigation from natural sources [24-26]. The final optimal conditions for the separation of volatile compounds were as follows: HP-5MS column using DVB/CAR/PDMS fibre for adsorbing compounds at $80{ }^{\circ} \mathrm{C}$ for $15 \mathrm{~min}$ and desorption in the GC port for $2 \mathrm{~min}$.

\subsection{Antioxidant Activity}

\subsubsection{DPPH Method}

The AOX of the Arctostaphylos uva-ursi was determined by the DPPH method [15]. A stock solution of $1000 \mu \mathrm{g} / \mathrm{g}$ of DPPH in pure methanol was prepared and homogenized for $30 \mathrm{~min}$ in an ultrasonic bath. The ultrasound-assisted extraction was performed at room temperature without heating. The temperature of vials during extraction increases insignificantly what doesn't influence sample composition. Then $12 \mathrm{~g}$ of stock solution was taken to obtain a solution of $30 \mu \mathrm{g} / \mathrm{g}$ of DPPH in $400 \mathrm{~g}$ of methanol $(\rho=0.792 \mathrm{~g} / \mathrm{mL})$. The reaction tube was wrapped in aluminium foil and stored in darkness. All samples of Arctostaphylos uva-ursi leaves were extracted in a Branson 3510 ultrasound bath with frequency of $40 \mathrm{~Hz}$ at room temperature for $30 \mathrm{~min}$ by adding $10 \mathrm{~g}$ of $80 \%(v / v)$ methanol to $0.1 \mathrm{~g}$ of leaves. Double extraction was performed, and both supernatants were combined. The final supernatant was then filtered $(0.45 \mathrm{~mm})$ and stored at $4{ }^{\circ} \mathrm{C}$ until being analyzed. Then, five different dilutions of supernatant were prepared with final concentrations of 0.17 , $0.35,0.70,1.40$ and $3.00 \mu \mathrm{g} / \mathrm{g}$. These concentrations have been determined experimentally by testing different concentrations of extract. The $100 \mu \mathrm{L}$ of each of them were mixed with $3.5 \mathrm{~mL}$ of $30 \mu \mathrm{g} / \mathrm{g}$ solution of DPPH. Absorbance at $515 \mathrm{~nm}$ after $15 \mathrm{~min}$ of the reaction was measured with a spectrophotometer (UV 1700, Shimadzu). All measurements were performed against blank (pure methanol). Moreover, blank of the sample was measured (3.5 $\mathrm{mL}$ of $30 \mu \mathrm{g} / \mathrm{g}$ solution of DPPH $+100 \mu \mathrm{L}$ of $80 \%$ methanol). All samples were prepared in triplicate. The results are expressed as a half-maximal inhibitory concentration $\left(\mathrm{IC}_{50}\right)$.

\subsubsection{ORAC Method}

The ORAC assay is based on the free radical reaction initiated by AAPH radicals. These react with a fluorescent substrate (fluorescein), giving rise to a non-fluorescent product. Therefore, the substrate concentration can be measured specifically, without interference and with high sensitivity. The reaction between AAPH and fluorescein is monitored by the decay of the fluorescent signal. The procedure according to Bentayeb et al. [27] was applied to performed the ORAC assay. 
Firstly, $1 \mathrm{~L}$ of $0.075 \mathrm{M}$ sodium phosphate buffer at $\mathrm{pH}=7$ was prepared by mixing $4.04 \mathrm{~g}$ of sodium dihydrogen phosphate monohydrate and $8.14 \mathrm{~g}$ of disodium hydrogen phosphate dihydrate. Then $30 \mathrm{~mL}$ of $34.4 \mathrm{mg} / \mathrm{g}$ AAPH and $30 \mathrm{~mL}$ of $2.3 \mu \mathrm{g} / \mathrm{g}$ fluorescein solutions in previously prepared sodium phosphate buffer were prepared. The $2.3 \mu \mathrm{g} / \mathrm{g}$ fluorescein solution was prepared from $1000 \mu \mathrm{g} / \mathrm{g}$ stock solution of fluorescein in sodium phosphate buffer. The analysis was performed by mixing $800 \mu \mathrm{L}$ of fluorescein with $100 \mu \mathrm{L}$ of Arctostaphylos uva-ursi extract and $600 \mu \mathrm{L}$ of AAPH and injecting them into an Alliance 2795 Separation Module (Waters, Milford, MA, USA) equipped with a 474 scanning fluorescence detector $\left(\lambda_{\text {excitation }}=491 \mathrm{~nm}\right.$ and $\left.\lambda_{\text {emission }}=515 \mathrm{~nm}\right)$. The system time running was set at $60 \mathrm{~min}$, with 50 total injections/hour. The fluorescence intensity was measured every minute to obtain a fluorescein decay curve. The samples acquisition was performed at $40{ }^{\circ} \mathrm{C}$ without chromatographic column with water as the mobile phase and $0.5 \mathrm{~mL} / \mathrm{min}$ flow. Injection volume was $20 \mu \mathrm{L}$. The concentration of extract has been determined experimentally by testing different dilutions of extract. Also blank was injected ( $800 \mu \mathrm{L}$ of fluorescein $+100 \mu \mathrm{L}$ of $80 \%$ methanol $+600 \mu \mathrm{L}$ of AAPH). All samples were analyzed in triplicate. The results are expressed as Trolox equivalents. Trolox, used as a reference antioxidant, was dissolved in sodium phosphate buffer. The following concentrations of Trolox required for the calibration curve were prepared: 0, 50, 100, 150, 200, $250 \mu \mathrm{g} / \mathrm{g}$.

\subsubsection{Total Phenolic Content}

The total phenolic content was measured on the methanolic extracts obtained using $50 \mathrm{mg}$ of dried sample and $10 \mathrm{~mL}$ of $80 \%$ methanol $(v / v)$ incubated for $30 \mathrm{~min}$ in an ultrasonic bath. The extracts were then filtered $(0.45 \mathrm{~mm})$ and stored at $4{ }^{\circ} \mathrm{C}$ until being analyzed. The extracts have been analyzed during $24 \mathrm{~h}$ after extraction. The Folin-Ciocalteu method $[28,29]$ with slight modifications was applied as follows: $0.1 \mathrm{~mL}$ of extract was mixed with $0.5 \mathrm{~mL}$ of pure Folin-Ciocalteu reagent, $0.4 \mathrm{~mL}$ of $80 \%(v / v)$ ethanol and $8 \mathrm{~mL}$ of ultrapure water. Then the mixture was ultrasound with frequency of $40 \mathrm{~Hz}$ at room temperature for $30 \mathrm{~min}$. In next step $1 \mathrm{~mL}$ of $20 \%(w / v) \mathrm{Na}_{2} \mathrm{CO}_{3}$ has been added and the reaction tubes have been kept in the dark for $30 \mathrm{~min}$ and the absorbance at $760 \mathrm{~nm}$ has been read using a UV2 UV/Vis spectrometer (ATI UNICAM, Collegeville, PA, USA). All measurements were performed against blank $(0.4 \mathrm{~mL}$ of $80 \%(v / v)$ ethanol $+8 \mathrm{~mL})$. All samples were prepared in triplicate. Five concentrations of gallic acid $(40,80,160,240$, $340 \mathrm{mg} / \mathrm{kg}$ ) have been prepared to construct the calibration curve. The concentration of total phenols has been calculated using the calibration curve and has been expressed as $\mathrm{mg}$ equivalents of gallic acid (GAE) per gram of dry weight of sample (mg GAE/g DW).

\subsubsection{Statistical Analysis}

The relative area of each detected compound was used in multivariate analysis. The area under the peak was related to the area of tetradecane, an endogenous compound present in all samples and placed in the centre of the chromatogram. The tetradecane was present at roughly the same level in all the samples. Principal component analysis (PCA) was performed using The Unscrambler X CAMO software ${ }^{\odot} 2016$ from Camo (Oslo, Norway). Projections to latent structures discriminant analysis (PLS-DA) model building and Pearson $r$ correlation with hierarchical clustering (HCA) were performed using online software MetaboAnalyst 4.0, which supports comprehensive metabolomics data analysis. The data matrix of $107 \times 27$ was applied. Pareto scaling (mean-centred and divided by the square root of each variables' standard deviation) was performed to scale the data.

\section{Results and Discussion}

\subsection{Optimisation of HS-SPME-GC-MS Conditions}

Optimization was performed to achieve the simultaneous detection of the highest possible number of volatile compounds. First of all, the BP-20 capillary column was chosen instead of the HP- 5 capillary column, as more peaks were observed in the polar BP-20 column. This indicates that the analyzed samples contained more polar compounds. The cho- 
sen column has a very polar polyethene glycol (PEG) stationary phase, suited for analysing alcohols, ketones, aldehydes, and esters. At the same time, HP-5 is a precision-engineered (5\%-phenyl)-methylpolysiloxane low polarity column. The results are consistent with the expectations, as according some authors the major secondary volatile metabolites from plant origin are better retained and seen in polar capillary columns like the BP-20 one [30,31]. In optimizing SPME extraction, many compounds were seen using DVB/CAR/PDMS fibre with adsorbent, bipolar coating suitable for 40-350 analyte molecular weight range. Polar analytes are better extracted using polar/bipolar fibres.

The obtained results agree with the literature $[24,32,33]$ as triphasic fibre is the most effective for sample compounds in a wide range of volatility and polarity. Moreover, coatings with adsorbent properties are better for trace level analytes with a narrower linear range. The optimum extraction conditions were as follows: extraction temperature: $80^{\circ} \mathrm{C}$, extraction time: $30 \mathrm{~min}$ and desorption time: $2 \mathrm{~min}$.

\subsection{Qualitative Analysis}

Untargeted metabolomics let one determine a considerable number of chemical compounds, often never-before-studied, in a single sample injection. This research aimed to screen all possible molecules present in the sample, focusing on antioxidant markers. The HS-SPME-GC-MS application combined with high-scoring library spectrum matches allowed us to successfully perform a qualitative analysis of a wide range of volatile bioactive compounds from Spanish Arctostaphylos uva-ursi samples. An example of the obtained chromatograms is shown in Figure 1. Also legend to Figure 1 has been presented as Table 2.

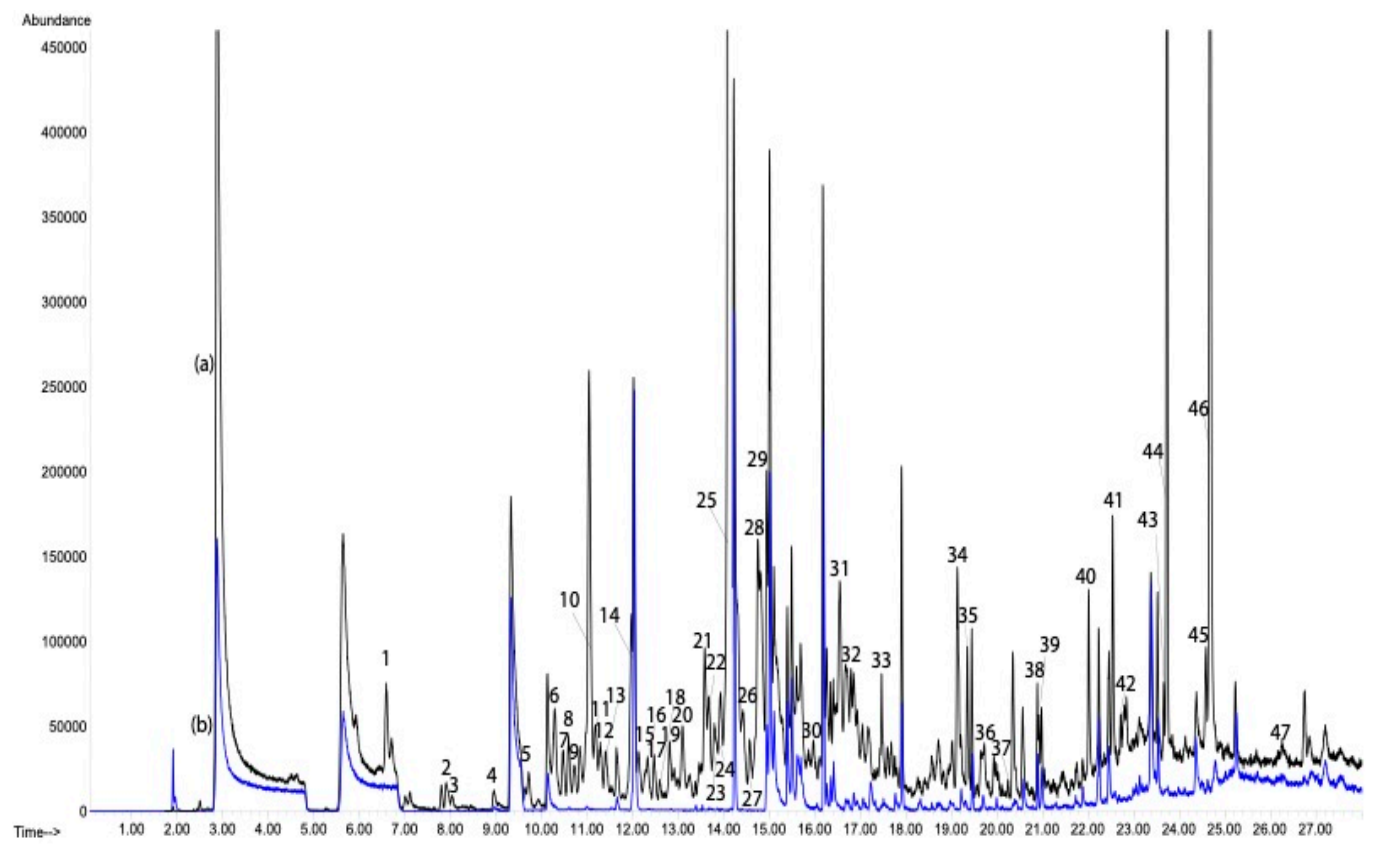

Figure 1. Chromatogram of (a) AL sample-leaves mixture from all collected plants from Albarracín (black line) compared to (b) blank (empty vial) (blue line) obtained by HS-SPME-GC-MS. Legend has been presented in Table 2. 
Table 2. Legend for Figure 1 presenting list of compounds numbered on the chromatogram.

\begin{tabular}{|c|c|}
\hline Number & Compound \\
\hline 1 & 4-Ethyldecane \\
\hline 2 & Docosyl octyl ether \\
\hline 3 & 3,8-Dimethyldecane \\
\hline 4 & Lysergamide \\
\hline 5 & 1-Iodododecane \\
\hline 6 & Dodecane \\
\hline 7 & 3,8-Dimethylundecane \\
\hline 8 & 4-Ethylundecane \\
\hline 9 & 2,3,7-Trimethyldecane \\
\hline 10 & 5-Ethyl-5-methyldecane \\
\hline 11 & 2,3,6-Trimethyldecane \\
\hline 12 & 5-Ethylundecane \\
\hline 13 & 3,5-Dimethylpiperidine \\
\hline 14 & 4,8-Dimethylundecane \\
\hline 15 & Tridecane \\
\hline 16 & Docosyl nonyl ether \\
\hline 17 & 2-Hexyl-1-decanol \\
\hline 18 & 1-Hexadecanol \\
\hline 19 & 1,2,4-Trimethylcyclohexane \\
\hline 20 & 6-Methyl-5-hepten-2-one \\
\hline 21 & 1-Iodotetradecane \\
\hline 22 & Tetradecane \\
\hline 23 & Eicosyl nonyl ether \\
\hline 24 & Methoxyacetic acid 2-tetradecyl ester \\
\hline 25 & Heptyl isobutyl ketone \\
\hline 26 & 1,3-bis(1,1-Dimethylethyl)-benzene \\
\hline 27 & Pentadecane \\
\hline 28 & 2,4-Heptadienal \\
\hline 29 & 3-Ethyl-1,4-hexadiene \\
\hline 30 & 2-Methylpentadecane \\
\hline 31 & Hexadecane \\
\hline 32 & 2,6,6-Trimethyl-1-cyclohexene-1-carboxaldehyde \\
\hline 33 & Fumaric acid 3-methylbut-3-enyl undecyl ester \\
\hline 34 & 2,4-Dimethylbenzaldehyde \\
\hline 35 & Geranyl acetone isomer 1 \\
\hline 36 & Tricyclo $[4,4,0,0(2,8)]$ decane \\
\hline 37 & 3-Buten-2-one \\
\hline 38 & $\beta$-Ionone \\
\hline
\end{tabular}


Table 2. Cont.

\begin{tabular}{ll}
\hline Number & Compound \\
\hline 39 & Phenol \\
\hline 40 & 6,10,14-Trimethyl-2-pentadecanone \\
\hline 41 & 2-Propanone \\
\hline 42 & Fumaric acid 2-decyl dodecyl ester \\
\hline 43 & dihydromethyljasmonate \\
\hline 44 & 2,4-di-tert-Butylphenol \\
\hline 45 & 1,2-Benzenedicarboxilic acid \\
\hline 46 & 5,6,7,7a-Tetrahydro-4,4,7a-trimethyl-2(4H)-benzofuranone \\
\hline 47 & Butyl octyl phthalate \\
\hline
\end{tabular}

Table A1 presented in Appendix A, shows the compounds and their structures determined in Arctostaphylos uva-ursi leaves samples using untargeted metabolomics.

Table A2 presented Appendix A, shows the compounds identified in different samples and their chemical classification.

During the screening of Arctostaphylos uva-ursi leaves samples, 107 different volatile compounds were detected. They were classified according to their chemical groups. Analyzing the data from the AOX point of view, the most interesting detected compounds were aromatic compounds, then phenols and finally esters.

Esters are organic chemical compounds condensation products of acids and alcohols or phenols. Strong antioxidants can be distinguished among them, such as fumaric and oxalic acid esters [34,35] and dihydromethyljasmonate, which were proven to reduce the decay and improve the antioxidant capacities of berries [36].

Discrimination of plant samples from the same species but different geographical regions might help control the type and concentration of metabolites produced by plants. It also lets one determine the best antioxidant profile of volatile compounds of plant origin. Therefore, a numerical classification of the Arctostaphylos uva-ursi leaves samples was performed using principal component analysis. The classes corresponding to each type of sample were modelled. Figure 2 shows the results of the PCA analysis.

The PCA (Figure 2a) shows that samples collected from Huétor (Granada) and Los Velez (Almería) formed a cluster. After connecting of this data with information from Table 1 some interesting conclusions can be reached. The observed results can be related to geographical closeness and the similar altitude of the harvest areas. Even though samples were collected in two different months the insolation was similar, also influencing the obtained results. Another cluster is observed in case of samples from Chelva (Valencia) and El Toro (Castellón). Although these two harvest areas are not located closely to each other their insolation and altitude were the same. Moreover, it has been seen that there is no cluster in case of Pina de Montalgrao and El Toro, locations from the same province (Castellón). Even though they are geographically close and exposed to the same solar radiation in September, the different altitudes influenced the chemical composition of Arctostaphylos uva-ursi collected from these areas. Then samples from Loarre (Huesca) collected during two different months were not grouped into cluster. This is attributed to the fact the solar radiation that in November is half of that in September. 

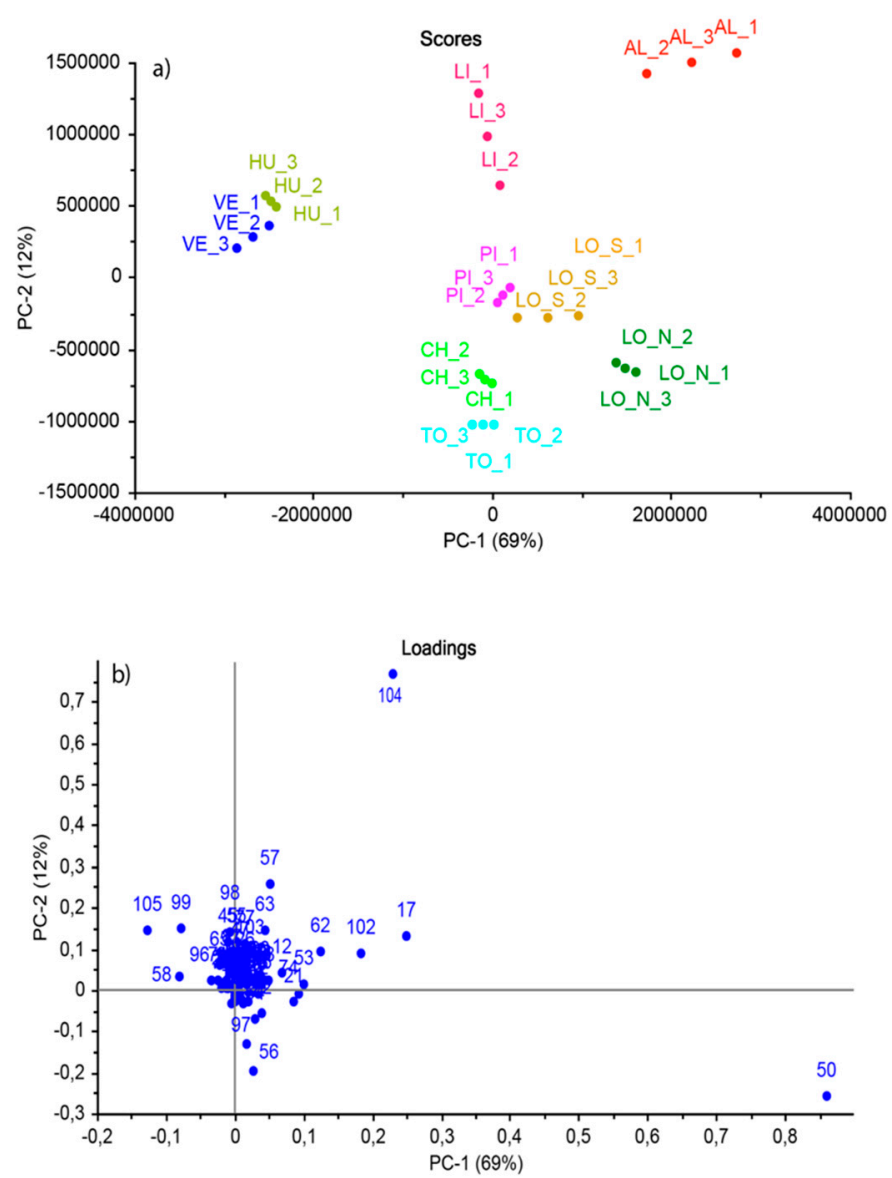

Figure 2. Results of PCA analysis where (a) graph of scores, numbers 1-3 indicate three replicates of the same sample; (b) graph of loadings, numbers of loadings indicate compounds presented in Appendix A Table A1.

On the other hand, samples from Albarracín (Teruel) and Lierta (Huesca) didn't cluster with any other sample. Samples from Albarracín are close on the score plot to the Pina de Montalgrao (Castellón) one, however they didn't cluster together probably because there is a difference in the altitude of the harvest sites, while in case of samples from Lierta it may be due to the lowest altitude of all locations.

Figure $2 \mathrm{~b}$ of the loading plot shows how strongly each characteristic (each compound) influences a principal component. First, the distribution of variables indicates which are significantly different and important. Variables placed close to the loading graph centre play a minor role in the analyzed samples. Moreover, the correlation between each characteristic can be read, checking the variables angles. It can be done using vectors, starting at the origin of PCs (PC-1 = 0 and PC-2 $=0$ ) and finishing at the points of variables. When the small angle is created between two vectors, and therefore variables are closed, they are positively correlated. In this case it is true for numbers 58, 99, 105 (group 1), 17, 53, 62, 102 (group 2) and 56, 97 (group 3) representing compounds as: group 1 (mequinol, 5-pentyl-1,3-benzenediol and benzoic acid); group 2 (2,4-di-tert-butylphenol, hexadecane, 2,3,6-trimethyldecane and 2,4-heptadienal); group 3 (4-(1-hydroxyallyl)-2-methoxyphenol and 1-ethylcyclohexene). Then, when the two variables angle is $90^{\circ}$, there is no correlation. An example can be numbers 21 and 98 representing 2-propanone and tridecane. Finally, when two variables diverge and form a large angle (close to $180^{\circ}$ ), they are negatively correlated. The example can be numbers 50 and 105 representing mequinol and 1,3-bis(1,1dimethylethyl)-benzene. All compounds together with their numbers are presented in Table A1 as Appendix A. PCA results show clear differentiation of samples. However, to determine the compounds responsible for it, further data analysis is required. 
Comparing Figure 2a,b a tendency can be seen. Figure 2a shows that earlier point samples (Los Vélez and Huétor) have lower values (negative) for PC-1 along its axis. As the scale increases the later points have higher values for PC-1 scores which are on positive side of PC-1. There is a clear trend with maximum positive values for samples from Albarracín (Teruel) and Loarre (Huesca) collected in November. Analysis of both score and loading plot together allow one to link together the samples and variables. Samples that have low values for PC-1 score have relatively higher values for variables from negative side of PC- 1 axis in loading plot. Those characteristic loadings are 58, 99 and 105 corresponding to benzoic acid, 5-pentyl-1,3-benzenediol and mequinol, respectively, compounds present in one or both samples AL and LO_N (Table A2 Appendix A). Moreover, mequinol (compound 105 ) is present in Figure 3 (which description has been presented below) as an important metabolite (red colour) for those two samples.

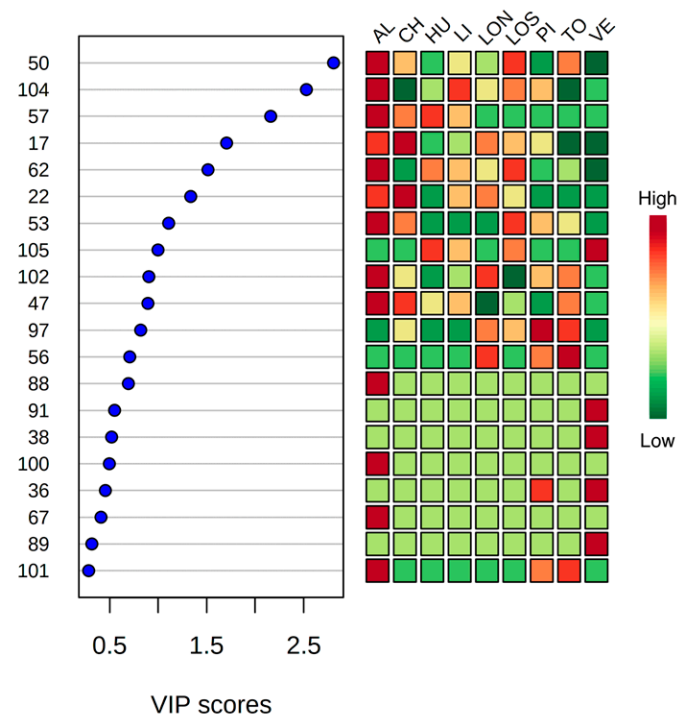

Figure 3. Representation of the twenty most important metabolites ranked by PLS-DA VIP score. The mini heatmap on the right indicates variations of their relative intensities in 9 different samples of Arctostaphylos uva-ursi.

In contrast for the variables in positive side of PC-1 the later points samples (Albarracín and Loarre collection in November) have relatively higher values for variables from positive side of PC-1 axis in loading plot. Those characteristic loadings are 50 and 104 corresponding to 1,3-bis(1,1-dimethylethyl)benzene and 5,6,7,7a-tetrahydro-4,4,7a-trimethyl$2(4 H)$-benzofuranone. Those compounds are characterized by the highest relative area of peaks in samples AL and LO_N.

Figure 3 shows PLS-DA analysis results, where the twenty most important metabolites are plotted according to the PLS-DA variable importance in projection (VIP) scores. VIP scores measure the importance and contribution of the variables to the PLS-DA model.

It can be seen in Figure 3 that the five most important metabolites and, at the same time, the compounds with the highest relative area in samples collected from Albarracín are 1,3bis(1,1-dimethylethyl)benzene, 3-ethyl-1,4-hexadiene, hexadecane, 2,3,6-trimethyldecane and 5,6,7,7a-tetrahydro-4,4,7a-trimethyl-2(4H)-benzofuranone. On the other hand, the most abundant compounds in the samples collected in Pina de Montalgrao are 4-(1hydroxyallyl)-2-methoxyphenol, 1-ethylcyclohexene, oxalic acid 6-ethyloct-3-yl ethyl ester and dihydromethyljasmonate. While the most abundant compounds in samples collected in Loarre $\mathrm{S}$ are 1,3-bis(1,1-dimethylethyl)benzene, 2,4-heptadienal, hexadecane and 5,6,7,7atetrahydro-4,4,7a-trimethyl-2(4H)-benzofuranone. These results are connected with the results of total phenolic content and different AOX measurements presented later.

All the most essential compounds determined by PCA, and PLS-DA were selected, and Pearson correlation analysis was performed and presented in Figure 4. The figure 
shows a positive correlation between the compounds obtained for compounds with $r>0.8$ (marked in red colour). It means that an increase in the relative area of one compound increases the relative area of another correlated compound in the same sample. An example can be the correlation between one ester and one phenol, such as dihydro methyl jasmonate and 2,4-di-tert-butylphenol. When $r=0$, there is no correlation. Finally, when $r$ is lower than 0 , there is a negative correlation between the compounds.

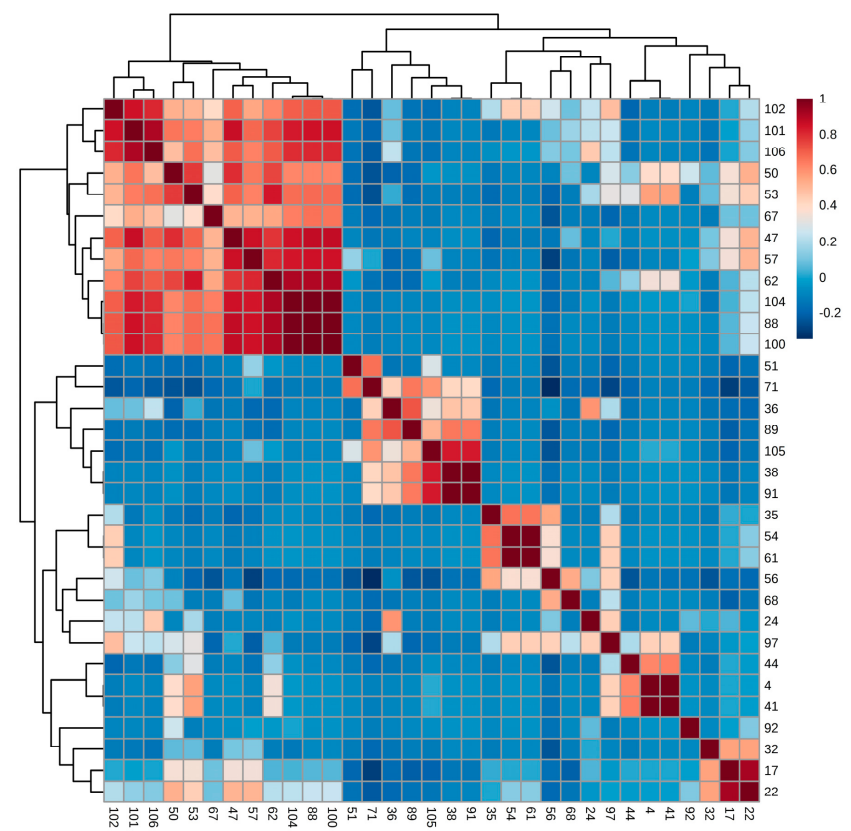

Figure 4. Results of Pearson correlation for the most important compounds presented as heat map with hierarchical clustering.

Moreover, four main clusters can be observed in the HCA analysis. Each cluster has a different group of compounds with a strong positive correlation between the relative intensities of compounds.

\subsection{Antioxidant Activity and Total Phenolic Content}

The AOX of chemical compounds and their mixtures can be explained by two mechanisms: hydrogen atom transfer (HAT) or single electron transfer (SET). The combination of both is also possible. In HAT, the antioxidant donates a hydrogen atom to free radical species to stabilize it. In SET, the antioxidant donates an electron to the target molecule. The chemical structure of the antioxidant compound determines the mechanism of AOX. It should be highlighted that plant extracts containing phenolic compounds synergistic effect can be observed. It influences AOX, and it depends on the type of compounds and their concentration [37]. Moreover, a single compound AOX can be changed in its mixture with other compounds by synergistic, additive, or antagonistic effect [38]. Different methods for evaluating AOX depend on the AOX mechanism, as described above.

Table 3 presents the AOX obtained by ORAC and DPPH methods. The half-maximal inhibitory concentration indicates the AOX of samples. In this case, the sample collected in Loarre in September has the strongest AOX. DPPH methods show the mixture of compounds that scavenge free radicals or act as hydrogen donors. 
Table 3. Results of antioxidant capacity obtained by ORAC and DPPH methods and total phenolic content.

\begin{tabular}{|c|c|c|c|}
\hline Sample & $\begin{array}{l}\text { CAOX DPPH * } \\
\text { IC }_{50}(\mu \mathrm{g} / \mathrm{g})\end{array}$ & $\begin{array}{c}\text { CAOX ORAC * } \\
\text { (g Trolox/g of Sample) }\end{array}$ & $\begin{array}{l}\text { Total Phenolic Content * } \\
\text { (mg GAE/g Sample DW) }\end{array}$ \\
\hline $\mathrm{AL}$ & $876 \pm 84$ & $29.96 \pm 0.50$ & $145.9 \pm 6.8$ \\
\hline $\mathrm{CH}$ & $824 \pm 82$ & $27.34 \pm 0.50$ & $167.2 \pm 10.2$ \\
\hline $\mathrm{HU}$ & $861 \pm 53$ & $27.46 \pm 0.50$ & $154.6 \pm 17.3$ \\
\hline LO_S & $711 \pm 12$ & $24.03 \pm 0.44$ & $171.9 \pm 19.4$ \\
\hline LO_N & $846 \pm 53$ & $27.78 \pm 0.51$ & $177.1 \pm 11.0$ \\
\hline LI & $1066 \pm 75$ & $28.77 \pm 0.53$ & $156.1 \pm 13.4$ \\
\hline PI & $1126 \pm 19$ & $33.11 \pm 0.61$ & $133.5 \pm 18.8$ \\
\hline $\mathrm{TO}$ & $922 \pm 116$ & $30.43 \pm 0.56$ & $146.9 \pm 13.0$ \\
\hline VE & $792 \pm 9$ & $24.95 \pm 0.46$ & $145.5 \pm 11.3$ \\
\hline
\end{tabular}

* Three replicates of each sample were analysed. Results are expressed as mean \pm SD.

On the other hand, in the case of the ORAC method, the high values of the obtained results indicate strong AOX of the plant extracts. In this case, the sample collected in Pina de Montalgrao has the strongest AOX. The ORAC method shows the extracts contain compounds with good electron donor capacities. Analyzing the results, an interesting tendency can be seen, as both methods correspond to different antioxidant mechanisms. Thus, the sample with the best AOX measured by the DPPH method has the lowest AOX measured by the ORAC method and vice-versa. Therefore, the obtained results indicate that the sample LO_S contains a high number of compounds acting as hydrogen donors and very few compounds acting as hydrogen donors, while an opposite tendency is seen in the case of the PI sample.

It should be highlighted that the methods applied for evaluating AOX are not specific to volatile compounds. Obtained results of AOX can be related to both volatile and non-volatile compounds. Qualitative analysis of non-volatile compounds in samples of Arctostaphylos uva-ursi was presented in our previous work [21].

Methanolic extracts prepared from samples collected in September and November 2015 were employed for total phenol content determinations. The total phenolic contents results show that it ranges from $133.5 \pm 18.8 \mathrm{mg}$ GAE/g DW (sample PI) to $177.1 \pm 11.0 \mathrm{mg} \mathrm{GAE} / \mathrm{g}$ DW (LO_N). The plant with the highest total phenolic content was the Loarre sample collected in September $(171.9 \pm 19.4 \mathrm{mg}$ GAE$/ \mathrm{g}$ DW) and November $(177.1 \pm 11.0 \mathrm{mg}$ $\mathrm{GAE} / \mathrm{g}$ DW) and the region with the lowest total phenolic content was Pina de Montalgrao $(133.5 \pm 18.8 \mathrm{mg} \mathrm{GAE} / \mathrm{g}$ DW). These results agree with the results obtained in the AOX study, showing similar behaviour in the same two populations.

\section{Antioxidant Markers}

All data presented in this investigation based on the untargeted metabolomics performed by HS-SPME-GC-MS completed with data analysis by chemometric tools let us identify antioxidants as quality markers shown in Table 4.

The determination of antioxidants as quality markers allows the differentiation of samples from different locations. In this case, 20 quality markers were proposed for samples of Arctostaphylos uva-ursi. Moreover, it facilitates samples characterization, quality control, AOX control and even authentication in case of fraud. It could also be applied to deal with the problem of product counterfeiting and inflated product prices. 
Table 4. Selected quality markers. Symbol "•" means that compound was present in a sample.

\begin{tabular}{|c|c|c|c|c|c|c|c|c|c|c|c|}
\hline No & Compound * & Class & $\mathbf{A L}$ & $\mathrm{CH}$ & HU & LO_S & LO_N & LI & PI & TO & $\mathrm{VE}$ \\
\hline 1 & oxalic acid 6-ethyloct-3-yl ethyl ester & ester & & & & & & & $\bullet$ & $\bullet$ & $\bullet$ \\
\hline 2 & $\begin{array}{l}\text { 3-(3,4-dimethoxyphenyl)-6- } \\
\text { nitrocoumarin }\end{array}$ & aromatic & & & $\bullet$ & & & & & & $\bullet$ \\
\hline 3 & methoxyacetic acid 2-tetradecyl ester & ester & $\bullet$ & $\bullet$ & $\bullet$ & $\bullet$ & & $\bullet$ & $\bullet$ & $\bullet$ & - \\
\hline 4 & 1,3-bis(1,1-dimethylethyl)benzene & aromatic & - & - & - & - & - & - & - & - & - \\
\hline 5 & 2,4-heptadienal & aldehyde & - & • & & - & & & - & - & \\
\hline 6 & 3-ethyl-1,4-hexadiene & diene & $\bullet$ & $\bullet$ & $\bullet$ & & & $\bullet$ & & & \\
\hline 7 & benzoic acid & $\begin{array}{l}\text { carboxylic } \\
\text { acid }\end{array}$ & & & & - & & & & & $\bullet$ \\
\hline 8 & $\begin{array}{l}\text { 2,6,6-trimethyl-1-cyclohexene-1- } \\
\text { carboxaldehyde }\end{array}$ & aldehyde & - & & & & & - & - & - & \\
\hline 9 & $\begin{array}{l}\text { fumaric acid 3-methylbut-3-enyl } \\
\text { undecyl ester }\end{array}$ & ester & - & & & & & & & & \\
\hline 10 & phenol & phenol & $\bullet$ & & & & & & & & \\
\hline 11 & [(2-methylpropyl)thio]-benzene & aromatic & & & & & & & & & - \\
\hline 12 & glycerol 1,2-diacetate & ester & & & & & & & & & - \\
\hline 13 & 3-furanacetic acid & $\begin{array}{l}\text { carboxylic } \\
\text { acid }\end{array}$ & & & & & & & & & $\bullet$ \\
\hline 14 & 4-(1-hydroxyallyl)-2-methoxyphenol & phenol & & $\bullet$ & & $\bullet$ & $\bullet$ & & $\bullet$ & $\bullet$ & \\
\hline 15 & 5-pentyl-1,3-benzenediol & alcohol & & & - & & & - & & & \\
\hline 16 & fumaric acid 2-decyl dodecyl ester & ester & - & & & & & & & & \\
\hline 17 & dihydromethyljasmonate & ester & - & & & & & & - & - & \\
\hline 18 & 2,4-di-tert-butylphenol & phenol & - & - & - & & - & - & - & - & - \\
\hline 19 & $\begin{array}{l}\text { 5,6,7,7a-tetrahydro-4,4,7a-trimethyl- } \\
2(4 H) \text {-benzofuranone }\end{array}$ & terpene & - & & • & & & $\bullet$ & $\bullet$ & - & - \\
\hline 20 & mequinol & phenol & & & • & & & • & & & • \\
\hline
\end{tabular}

* Three replicates of each sample were analysed.

\section{Conclusions}

The untargeted metabolomics method was applied in a single injection of different samples of Spanish Arctostaphylos uva-ursi to perform a qualitative analysis of their volatile bioactive compounds. The novelty of this investigation is that for the first time VOC quality markers for the Arctostaphylos uva-ursi plant collected from various Spanish locations were determined and the influence of parameters such as geographical closeness, altitude and insolation of harvest areas have been demonstrated. The investigation was, focus mainly on antioxidant markers. As an analytical method, HS-SPME-GC-MS was optimized and applied.

One-hundred seven different volatile compounds were detected and classified according to their structure. The most interesting detected compounds that potentially may be antioxidant markers were for example fumaric acid 2-decyl dodecyl ester for Albarracín (Teruel), 4-(1-hydroxyallyl)-2-methoxyphenol for Chelva (Valencia), El Toro (Castellón) and both samples from Loarre (Huesca), dimethoxyphenyl-6-nitro-coumarin for Huétor (Granada) and Los Vélez (Almería) samples, 5-pentyl-1,3-benzenediol for Lierta (Huesca), and oxalic acid 6-ethyloct-3-yl ethyl ester for Pina de Montalgrao (Castellón).The chromatographic and chemometric analysis showed that the same Arctostaphylos uva-ursi collected from different locations have different antioxidant profiles. Parameters such as geographical closeness, solar radiation and altitude have been crucial for samples clustering. PCA, PLS-DA and Pearson correlation analysis connect individual compounds with AOX properties and total phenolic content. It was concluded that the extract from the plant from Pina de Montalgrao was rich in electron-donor compounds.

The strongest AOX was obtained in the samples from Pina de Montalgrao and Loarre (collected in September) according to both the ORAC and DPPH methods. In contrast, the extract from Loarre (collected in September) was rich in free radical scavengers and 
hydrogen-donor compounds. The total phenols results agree with the results obtained in the AOX study.

It should be mentioned that the presented study also has limitations due to the analytical method applied. The proposed study doesn't detect all possible compounds present in the samples. Complete profile of metabolites should contain also non-volatile compound detected by UPLC methods as non-volatile fraction has its own contribution to AOX. It should be highlighted that such a study has been already performed as the first part of this investigation project [21,22]. On the other hand, it is also possible that not all the volatile compounds present in the samples were detected. It is due to the selection of specific fiber for SPME and a specific type of chromatographic column.

The results may allow in the future the creation of mixtures of extracts of the same plant with different AOX properties that would be applied in the food industry area, for example as dietary supplements, food additives, and active packaging components. Moreover, plants from specific locations can be collected to obtain extracts with targeted compounds with unique properties. For this purpose, the extracts and plants' characterisation is fundamental to guarantee authentication and avoid fraud, which is pretty standard in plants, spices, and herbal extracts. The list of quality markers for the analyzed samples is provided.

Author Contributions: Conceptualization, M.W., D.P., C.N. and E.A.; methodology, D.P., M.A.R. and P.V.; software, D.P.; validation, M.W., D.P., M.A.R. and P.V; formal analysis, M.W. and P.V.; investigation, M.W., D.P., M.A.R. and P.V.; data curation, M.W., D.P., M.A.R. and P.V.; writingoriginal draft preparation, M.W., D.P., M.A.R.; writing—review and editing, M.W., D.P., C.N. and E.A.; visualization, M.W. and D.P.; supervision, C.N. and E.A.; project administration, C.N. and E.A.; funding acquisition, C.N. and E.A. All authors have read and agreed to the published version of the manuscript.

Funding: This research received no external funding.

Institutional Review Board Statement: Not applicable.

Informed Consent Statement: Not applicable.

Data Availability Statement: Not applicable.

Acknowledgments: Many thanks are given to Ester Sales for providing the samples. Thanks are also given to Gobierno de Aragón and Fondo Social Europeo for the financial help given to GUIA group T53_20R.

Conflicts of Interest: The authors declare no conflict of interest.

\section{Appendix A}

Table A1. Qualitative results of Arctostaphylos uva-ursi leaves (all samples) made by HS-SPME-GC-MS. List presents all compounds detected during the experiments.

\begin{tabular}{ccccc}
\hline No & $\begin{array}{c}\mathbf{t R} \\
(\mathbf{m i n})\end{array}$ & Compound * $^{*}$ & CAS & Structure \\
\hline 1 & 6.58 & 4-ethyldecane & $1636-44-8$ \\
2 & 7.77 & 5-methylundecane & $1632-70-8$ & 1144 \\
3 & 7.81 & 2-butyl-1-octanol & $3913-02-8$ & 1146 \\
\hline
\end{tabular}


Table A1. Cont.

\begin{tabular}{|c|c|c|c|c|c|}
\hline No & $\begin{array}{c}\mathrm{tR} \\
(\mathrm{min})\end{array}$ & Compound * & CAS & Structure & KI \\
\hline 4 & 7.81 & carbonic acid decyl nonyl ester & $1000383-15-8$ & & 1146 \\
\hline 5 & 7.90 & docosyl octyl ether & $1000406-38-9$ & M & 1150 \\
\hline 6 & 7.91 & hexyl pentyl ether & $32357-83-8$ & & 1150 \\
\hline 7 & 8.03 & 3,8-dimethyldecane & $17312-55-9$ & & 1155 \\
\hline 8 & 8.031 & 2-propyl-1-heptanol & $10042-59-8$ & & 1156 \\
\hline 9 & 8.95 & $\begin{array}{l}\text { N,N-bis(2,4-dimethylphenyl)- } \\
\text { acetamide }\end{array}$ & $52812-80-3$ & & 1197 \\
\hline 10 & 8.95 & lysergamide & $478-94-4$ & & 1197 \\
\hline 11 & 9.73 & 1-iodo-dodecane & $4292-19-7$ & & 1238 \\
\hline 12 & 10.29 & dodecane & $112-40-3$ & & 1268 \\
\hline 13 & 10.47 & 3,8-dimethyl-undecane & $17301-30-3$ & & 1278 \\
\hline 14 & 10.59 & 4-ethyl-undecane & $17312-59-3$ & & 1285 \\
\hline 15 & 10.71 & 2,3,7-trimethyl-decane & $62238-13-5$ & & 1291 \\
\hline 16 & 10.84 & 5-ethyl-5-methyl-decane & $17312-74-2$ & & 1298 \\
\hline 17 & 11.04 & 2,3,6-trimethyl-decane & $62238-12-4$ & & 1311 \\
\hline 18 & 11.18 & 5-ethyl-undecane & $17453-94-0$ & & 1319 \\
\hline 19 & 11.29 & 3,5-dimethyl-piperidine & $35794-11-7$ & & 1326 \\
\hline 20 & 11.41 & 4,8-dimethyl-undecane & $17301-33-6$ & & 1334 \\
\hline 21 & 11.97 & tridecane & $629-50-5$ & & 1369 \\
\hline 22 & 12.13 & docosyl nonyl ether & $1000406-37-9$ & & 1379 \\
\hline 23 & 12.33 & 11-methyldodecanol & $85763-57-1$ & & 1392 \\
\hline 24 & 12.33 & $\begin{array}{l}\text { 6-ethyl-3-octyl ester chloroacetic } \\
\text { acid }\end{array}$ & $1000279-99-8$ & & 1392 \\
\hline 25 & 12.33 & 2-heptyl-3-methyloxirane & $54125-39-2$ & & 1392 \\
\hline 26 & 12.33 & 2-hexyl-1-decanol & $2425-77-6$ & & 1392 \\
\hline
\end{tabular}


Table A1. Cont.

\begin{tabular}{|c|c|c|c|c|c|}
\hline No & $\begin{array}{c}\mathrm{tR} \\
(\mathrm{min})\end{array}$ & Compound * & CAS & Structure & KI \\
\hline 27 & 12.34 & decyl ether & $2456-28-2$ & & 1392 \\
\hline 28 & 12.42 & 1,1,4-trimethyl-cyclohexane & 7094-27-1 & & 1398 \\
\hline 29 & 12.47 & n-tridecan-1-ol & $112-70-9$ & & 1401 \\
\hline 30 & 12.47 & 1-hexadecanol & $36653-82-4$ & & 1401 \\
\hline 31 & 12.59 & 1,2,4-trimethyl-cyclohexane & $2234-75-5$ & & 1410 \\
\hline 32 & 12.59 & $\begin{array}{l}\text { 6-ethyl-3-octyl ester } \\
\text { trichloroacetic acid }\end{array}$ & $147-93-3$ & & 1410 \\
\hline 33 & 12.59 & $\begin{array}{l}\text { 1,1-dimethyl-2-propyl- } \\
\text { cyclohexane }\end{array}$ & $81983-71-3$ & & 1410 \\
\hline 34 & 12.60 & hexyl octyl ether & $17071-54-4$ & & 1410 \\
\hline 35 & 12.60 & diedecyl ester decanedioic acid & $2432-89-5$ & & 1410 \\
\hline 36 & 12.61 & $\begin{array}{l}\text { 6-ethyloct-3-yl ethyl ester oxalic } \\
\text { acid }\end{array}$ & $1000309-33-9$ & & 1411 \\
\hline 37 & 12.81 & 6-methyl-5-hepten-2-one & $100-93-0$ & & 1426 \\
\hline 38 & 12.82 & $\begin{array}{l}\text { 3-(3,4-dimethoxyphenyl)-6- } \\
\text { nitro-coumarin }\end{array}$ & 331949-94-1 & & 1426 \\
\hline 39 & 12.81 & $\begin{array}{l}\text { 2-isopropyl-5-methyl-1- } \\
\text { heptanol }\end{array}$ & $91337-07-4$ & & 1426 \\
\hline 40 & 12.91 & 2-methyl-tridecane & $1560-96-9$ & & 1433 \\
\hline 41 & 12.98 & $\begin{array}{l}\text { decyl undecyl ester carbonic } \\
\text { acid }\end{array}$ & $1000383-16-0$ & & 1439 \\
\hline 42 & 13.09 & 1-iodo-tetradecane & 19218-94-1 & & 1446 \\
\hline 43 & 13.24 & $\begin{array}{l}\text { 2,2,3,3,5,6,6-heptamethyl- } \\
\text { heptane }\end{array}$ & $7225-67-4$ & & 1458 \\
\hline 44 & 13.46 & $\begin{array}{l}\text { decyl dodecyl ester carbonic } \\
\text { acid }\end{array}$ & $1000383-16-1$ & & 1474 \\
\hline 45 & 13.58 & tetradecane & $629-59-4$ & & 1482 \\
\hline 46 & 13.67 & eicosyl nonyl ether & $1000406-37-8$ & & 1489 \\
\hline 47 & 13.80 & $\begin{array}{l}\text { 2-tetradecyl ester methoxyacetic } \\
\text { acid }\end{array}$ & $1000282-04-8$ & & 1499 \\
\hline 48 & 13.92 & heptyl isobutyl ketone & 19594-40-2 & & 1508 \\
\hline 49 & 13.92 & 2-methyl-tetratetradecane & $1560-95-8$ & & 1508 \\
\hline
\end{tabular}


Table A1. Cont.

\begin{tabular}{|c|c|c|c|c|c|}
\hline No & $\begin{array}{c}\mathbf{t R} \\
(\mathrm{min})\end{array}$ & Compound * & CAS & Structure & KI \\
\hline 50 & 14.10 & $\begin{array}{l}\text { 1,3-bis(1,1-dimethylethyl)- } \\
\text { benzene }\end{array}$ & $1014-60-4$ & & 1521 \\
\hline 51 & 14.32 & p-cymene & $99-87-6$ & & 1537 \\
\hline 52 & 14.56 & pentadecane & $629-62-9$ & & 1556 \\
\hline 53 & 14.74 & 2,4-heptadienal & $4313-03-5$ & & 1569 \\
\hline 54 & 14.75 & 1,3-dimethyl-1h-pyrazole & $694-48-4$ & & 1570 \\
\hline 55 & 14.76 & 2-ethyl-3-methylcyclopentene & $19780-56-4$ & & 1570 \\
\hline 56 & 14.81 & 1-ethyl-cyclohexene & $1453-24-3$ & & 1574 \\
\hline 57 & 14.81 & 3-ethyl-1,4-hexadiene & $2080-89-9$ & & 1575 \\
\hline 58 & 15.17 & benzoic acid & 3782-84-1 & & 1601 \\
\hline 59 & 15.28 & 2-octyl-1-decanol & $45235-48-1$ & & 1611 \\
\hline 60 & 15.97 & 2-methyl-pentadecane & $1560-93-6$ & & 1667 \\
\hline 61 & 16.10 & $\begin{array}{l}\text { tetradecyl vinyl ester carbonic } \\
\text { acid }\end{array}$ & $1000382-54-5$ & & 1678 \\
\hline 62 & 16.54 & hexadecane & $544-76-3$ & & 1715 \\
\hline 63 & 16.74 & $\begin{array}{l}\text { 2,6,6-trimethyl-1-cyclohexene- } \\
\text { 1-carboxaldehyde }\end{array}$ & $432-25-7$ & & 1731 \\
\hline 64 & 16.79 & beta-cyclocitral & $432-26-7$ & & 1738 \\
\hline 65 & 16.84 & 7-methyl-pentadecane & $6165-40-8$ & & 1743 \\
\hline 66 & 17.05 & sarcocapnidine & $87069-33-8$ & & 1762 \\
\hline 67 & 17.68 & $\begin{array}{l}\text { 3-methylbut-3-enyl undecyl } \\
\text { ester fumaric acid }\end{array}$ & $1000348-91-0$ & & 1819 \\
\hline 68 & 17.68 & $\begin{array}{l}\text { 3-methylbut-3-enyl pentadecyl } \\
\text { ester fumaric acid }\end{array}$ & $1000348-91-4$ & & 1819 \\
\hline 69 & 17.68 & octadecanoic acid & $57-11-4$ & & 1819 \\
\hline 70 & 18.22 & 2-methylene cyclobutanone & $17714-43-1$ & & 1868 \\
\hline
\end{tabular}


Table A1. Cont.

\begin{tabular}{|c|c|c|c|c|c|}
\hline No & $\begin{array}{c}\mathbf{t R} \\
(\mathrm{min})\end{array}$ & Compound * & CAS & Structure & KI \\
\hline 71 & 18.31 & naphthalene & $91-20-3$ & & 1876 \\
\hline 72 & 18.57 & isobutyl tetradecyl ether & $1000406-32-7$ & & 1899 \\
\hline 73 & 18.72 & isopropyl tetradecyl ether & 1000406-34-0 & & 1913 \\
\hline 74 & 19.13 & 2,4-dimethylbenzaldehyde & $15764-16-6$ & & 1955 \\
\hline 75 & 19.13 & benzaldehyde & $53951-50-1$ & & 1955 \\
\hline 76 & 19.18 & 3,5-dimethylbenzaldehyde & $5779-95-3$ & & 1960 \\
\hline 77 & 19.34 & geranyl acetone isomer 1 & $689-67-8$ & & 1976 \\
\hline 78 & 19.35 & geranyl acetone isomer 2 & $105-87-3$ & & 1977 \\
\hline 79 & 19.64 & benzyl alcohol & $100-51-6$ & & 2006 \\
\hline 80 & 19.72 & cis-2-(1-pentenyl)furan & $70424-13-4$ & & 2013 \\
\hline 81 & 19.93 & tricyclo $[4,4,0,0(2,8)]$ decane & $49700-59-6$ & & 2034 \\
\hline 82 & 19.93 & neophytadiene & $504-96-1$ & & 2034 \\
\hline 83 & 19.93 & $\begin{array}{l}\text { 5-methyleneoctahydro-1H- } \\
\text { indene }\end{array}$ & $1000152-00-6$ & & 2034 \\
\hline 84 & 19.93 & bicyclo[3,3,1]non-2-en-9-one & $4844-11-5$ & & 2035 \\
\hline 85 & 20.24 & cyclohexanol & $55000-30-1$ & & 2066 \\
\hline 86 & 20.35 & 3-buten-2-one & $79-77-6$ & & 2077 \\
\hline 87 & 20.92 & $\beta$-ionone & $23267-57-4$ & & 2134 \\
\hline 88 & 20.97 & phenol & $108-95-2$ & & 2141 \\
\hline 89 & 21.04 & [(2-methylpropyl)thio]-benzene & $13307-61-4$ & & 2148 \\
\hline 90 & 21.05 & $\begin{array}{c}\text { 2-isopropyl-5,5- } \\
\text { dimethylcyclohex-2-enone }\end{array}$ & $1000191-19-3$ & & 2149 \\
\hline
\end{tabular}


Table A1. Cont.

\begin{tabular}{|c|c|c|c|c|c|}
\hline No & $\begin{array}{c}t R \\
(\min )\end{array}$ & Compound * & CAS & Structure & KI \\
\hline 91 & 21.53 & glycerol 1,2-diacetate & $102-62-5$ & & 2200 \\
\hline 92 & 21.75 & 1-methylethyl benzoate & $939-48-0$ & & 2225 \\
\hline 93 & 22.01 & $\begin{array}{l}\text { 6,10,14-trimethyl-2- } \\
\text { pentadecanone }\end{array}$ & $502-69-2$ & & 2254 \\
\hline 94 & 22.02 & 6-methyl-2-tridecanone & 73105-73-4 & & 2255 \\
\hline 95 & 22.02 & 6,10-dimethyl-2-undecanone & $1604-34-2$ & & 2255 \\
\hline 96 & 22.058 & 3-furanacetic acid & $39212-21-0$ & & 2259 \\
\hline 97 & 22.54 & $\begin{array}{l}\text { 4-(1-hydroxyallyl)-2- } \\
\text { methoxyphenol }\end{array}$ & $112465-50-6$ & & 2313 \\
\hline 98 & 22.54 & 2-propanone & $2503-46-0$ & & 2313 \\
\hline 99 & 22.54 & 5-pentyl-1,3-benzenediol & $500-66-3$ & & 2313 \\
\hline 100 & 22.72 & $\begin{array}{l}\text { 2-decyl dodecyl ester fumaric } \\
\text { acid }\end{array}$ & $1000348-59-3$ & & 2334 \\
\hline 101 & 23.66 & dihydro methyl jasmonate & 24851-98-7 & & 2437 \\
\hline 102 & 23.73 & 2,4-di-tert-butylphenol & $96-76-4$ & & 2444 \\
\hline 103 & 24.59 & 1,2-benzenedicarboxilic acid & $88-99-3$ & & 2527 \\
\hline 104 & 24.68 & $\begin{array}{l}\text { 5,6,7,7a-tetrahydro-4,4,7a- } \\
\text { trimethyl-2(4h)-benzofuranone }\end{array}$ & $15356-74-8$ & & 2534 \\
\hline 105 & 24.88 & mequinol & $150-76-5$ & & 2551 \\
\hline 106 & 26.26 & butyl octyl phthalate & $84-78-6$ & & 2654 \\
\hline 107 & 26.76 & 2-methylbenzathiazole & $120-75-2$ & & 2687 \\
\hline
\end{tabular}


Table A2. Presence of detected volatile compounds in different samples: AL-Albarracín; $\mathrm{CH}-$ Chelva; HU-Huétor; LO_S_Loarre_September; LO_N-Loarre_November; LI-Lierta; PI—Pina de Montalgrao; TO_El Toro; VE—Los Vélez *. Symbol “•" means that compound was present in a sample ${ }^{* *}$.

\begin{tabular}{|c|c|c|c|c|c|c|c|c|c|c|c|}
\hline No & Compound * & Class & AL & $\mathrm{CH}$ & HU & LO_S & LO_N & LI & PI & TO & VE \\
\hline 1 & 4-ethyldecane & alkane & $\bullet$ & $\bullet$ & & & & $\bullet$ & $\bullet$ & - & \\
\hline 2 & 5-methylundecane & alkane & & & & & $\bullet$ & $\bullet$ & & & \\
\hline 3 & 2-butyl-1-octanol & alcohol & & & & & & $\bullet$ & $\bullet$ & $\bullet$ & \\
\hline 4 & decyl nonyl ester carbonic acid & ester & & & & $\bullet$ & & & & & \\
\hline 5 & docosyl octyl ether & ether & $\bullet$ & $\bullet$ & & $\bullet$ & & & $\bullet$ & $\bullet$ & \\
\hline 6 & hexyl pentyl ether & ether & & & & & $\bullet$ & & & & \\
\hline 7 & 3,8-dimethyl-decane & alkane & $\bullet$ & & & & & & $\bullet$ & $\bullet$ & \\
\hline 8 & 2-propyl-1-heptanol & alcohol & & & & $\bullet$ & & & & & \\
\hline 9 & $\begin{array}{l}\text { N,N-bis(2,4-dimethyl } \\
\text { phenyl)-acetamide }\end{array}$ & amide & & & & & & $\bullet$ & & & \\
\hline 10 & lysergamide & amide & $\bullet$ & & & & & & $\bullet$ & $\bullet$ & \\
\hline 11 & 1-iodo-dodecane & alkane & $\bullet$ & • & & $\bullet$ & $\bullet$ & & & & \\
\hline 12 & dodecane & alkane & $\bullet$ & $\bullet$ & & $\bullet$ & $\bullet$ & $\bullet$ & $\bullet$ & $\bullet$ & \\
\hline 13 & 3,8-dimethyl-undecane & alkane & $\bullet$ & $\bullet$ & & $\bullet$ & $\bullet$ & & $\bullet$ & $\bullet$ & \\
\hline 14 & 4-ethyl-undecane & alkane & $\bullet$ & $\bullet$ & & $\bullet$ & $\bullet$ & $\bullet$ & $\bullet$ & $\bullet$ & \\
\hline 15 & 2,3,7-trimethyl-decane & alkane & $\bullet$ & $\bullet$ & & & $\bullet$ & $\bullet$ & $\bullet$ & $\bullet$ & \\
\hline 16 & 5-ethyl-5-methyl-decane & alkane & $\bullet$ & $\bullet$ & & $\bullet$ & $\bullet$ & $\bullet$ & $\bullet$ & $\bullet$ & \\
\hline 17 & 2,3,6-trimethyl-decane & alkane & $\bullet$ & $\bullet$ & $\bullet$ & $\bullet$ & $\bullet$ & $\bullet$ & $\bullet$ & $\bullet$ & \\
\hline 18 & 5-ethyl-undecane & alkane & $\bullet$ & $\bullet$ & & $\bullet$ & $\bullet$ & $\bullet$ & $\bullet$ & $\bullet$ & \\
\hline 19 & 3,5-dimethyl-piperidine & amine & $\bullet$ & $\bullet$ & & $\bullet$ & $\bullet$ & $\bullet$ & $\bullet$ & $\bullet$ & \\
\hline 20 & 4,8-dimethyl-undecane & alkane & $\bullet$ & $\bullet$ & & $\bullet$ & $\bullet$ & $\bullet$ & $\bullet$ & $\bullet$ & \\
\hline 21 & tridecane & alkane & $\bullet$ & $\bullet$ & & $\bullet$ & $\bullet$ & & $\bullet$ & $\bullet$ & \\
\hline 22 & docosyl nonyl ether & ether & $\bullet$ & $\bullet$ & & $\bullet$ & $\bullet$ & $\bullet$ & & & \\
\hline 23 & 11-methyldodecanol & alcohol & & & & & & & & & $\bullet$ \\
\hline 24 & $\begin{array}{l}\text { 6-ethyl-3-octyl ester } \\
\text { chloroacetic acid }\end{array}$ & ester & & $\bullet$ & & & & $\bullet$ & $\bullet$ & $\bullet$ & \\
\hline 25 & 2-heptyl-3-methyloxirane & ether & & & & & $\bullet$ & & & & \\
\hline 26 & 2-hexyl-1-decanol & alcohol & $\bullet$ & & - & - & & & & & \\
\hline 27 & decyl ether & ether & & & & & & & & & \\
\hline 28 & 1,1,4-trimethyl-cyclohexane & alkane & & & & & & & & & $\bullet$ \\
\hline 29 & N-tridecan-1-ol & alcohol & & & & & & & - & $\bullet$ & \\
\hline 30 & 1-hexadecanol & alcohol & $\bullet$ & $\bullet$ & & & & & & & \\
\hline 31 & 1,2,4-trimethyl-cyclohexane & alkane & $\bullet$ & & & & & & & & \\
\hline 32 & $\begin{array}{l}\text { 6-ethyl-3-octyl ester } \\
\text { trichloroacetic acid }\end{array}$ & ester & & $\bullet$ & & & & & & & \\
\hline 33 & $\begin{array}{l}\text { 1,1-dimethyl-2-propyl- } \\
\text { cyclohexane }\end{array}$ & alkane & & & $\bullet$ & $\bullet$ & & & & & \\
\hline 34 & hexyl octyl ether & ether & & & & & & & & & \\
\hline 35 & diedecyl ester decanedioic acid & ester & & & & & $\bullet$ & & & & \\
\hline 36 & $\begin{array}{c}\text { 6-ethyloct-3-yl ethyl ester } \\
\text { oxalic acid }\end{array}$ & ester & & & & & & & $\bullet$ & $\bullet$ & $\bullet$ \\
\hline 37 & 6-methyl-5-hepten-2-one & ketone & $\bullet$ & $\bullet$ & & & $\bullet$ & $\bullet$ & & & \\
\hline 38 & $\begin{array}{c}\text { 3-(3,4-dimethoxy } \\
\text { phenyl)-6-nitro-coumarin }\end{array}$ & aromatic & & & $\bullet$ & & & & & & $\bullet$ \\
\hline 39 & 2-isopropyl-5-methyl-1-heptanol & alcohol & & & & $\bullet$ & & & & & \\
\hline 40 & 2-methyl-tridecane & alkane & & $\bullet$ & & • & $\bullet$ & & & & \\
\hline 41 & decyl undecyl ester carbonic acid & ester & & & & • & & & & & \\
\hline 42 & 1-iodo-tetradecane & alkane & $\bullet$ & • & & • & $\bullet$ & $\bullet$ & • & • & \\
\hline
\end{tabular}


Table A2. Cont.

\begin{tabular}{|c|c|c|c|c|c|c|c|c|c|c|c|}
\hline No & Compound * & Class & AL & $\mathrm{CH}$ & HU & LO_S & LO_N & LI & PI & TO & VE \\
\hline 43 & $\begin{array}{l}\text { 2,2,3,3,5,6,6-heptamethyl- } \\
\text { heptane }\end{array}$ & alkane & & $\bullet$ & & $\bullet$ & $\bullet$ & & $\bullet$ & $\bullet$ & \\
\hline 44 & decyl dodecyl ester carbonic acid & ester & & & & $\bullet$ & & & & & \\
\hline 45 & tetradecane & alkane & $\bullet$ & • & $\bullet$ & $\bullet$ & $\bullet$ & $\bullet$ & $\bullet$ & $\bullet$ & $\bullet$ \\
\hline 46 & eicosyl nonyl ether & ether & $\bullet$ & $\bullet$ & & $\bullet$ & $\bullet$ & $\bullet$ & $\bullet$ & $\bullet$ & $\bullet$ \\
\hline 47 & $\begin{array}{l}\text { 2-tetradecyl ester methoxyacetic } \\
\text { acid }\end{array}$ & ester & $\bullet$ & $\bullet$ & $\bullet$ & $\bullet$ & & $\bullet$ & $\bullet$ & $\bullet$ & $\bullet$ \\
\hline 48 & heptyl isobutyl ketone & ketone & $\bullet$ & - & $\bullet$ & & • & $\bullet$ & $\bullet$ & • & • \\
\hline 49 & 2-methyl-tetratetradecane & alkane & & & & $\bullet$ & & & & & \\
\hline 50 & $\begin{array}{l}\text { 1,3-bis(1,1-dimethylethyl)- } \\
\text { benzene }\end{array}$ & aromatic & $\bullet$ & - & $\bullet$ & - & $\bullet$ & $\bullet$ & $\bullet$ & $\bullet$ & $\bullet$ \\
\hline 51 & p-cymene & aromatic & & & $\bullet$ & & & & & & \\
\hline 52 & pentadecane & alkane & • & • & & $\bullet$ & - & $\bullet$ & $\bullet$ & - & \\
\hline 53 & 2,4-heptadienal & aldehyde & $\bullet$ & $\bullet$ & & $\bullet$ & & & $\bullet$ & $\bullet$ & \\
\hline 54 & 1,3-dimethyl-1h-pyrazole & amine & & & & & • & & & & \\
\hline 55 & 2-ethyl-3-methylcyclopentene & alkane & & & & & & $\bullet$ & & & \\
\hline 56 & 1-ethyl-cyclohexene & alkane & & & & & • & & $\bullet$ & • & \\
\hline 57 & 3-ethyl-1,4-hexadiene & diene & $\bullet$ & $\bullet$ & $\bullet$ & & & $\bullet$ & & & \\
\hline 58 & benzoic acid & $\begin{array}{l}\text { carboxylic } \\
\text { acid }\end{array}$ & & & & $\bullet$ & & & & & - \\
\hline 59 & 2-octyl-1-decanol & alcohol & & & & & $\bullet$ & & & & \\
\hline 60 & 2-methyl-pentadecane & alkane & $\bullet$ & & & & $\bullet$ & & & & \\
\hline 61 & $\begin{array}{c}\text { tetradecyl vinyl ester carbonic } \\
\text { acid }\end{array}$ & ester & & & & & • & & & & \\
\hline 62 & hexadecane & alkane & $\bullet$ & $\bullet$ & $\bullet$ & $\bullet$ & $\bullet$ & $\bullet$ & $\bullet$ & $\bullet$ & \\
\hline 63 & $\begin{array}{l}\text { 2,6,6-trimethyl-1-cyclohexene-1- } \\
\text { carboxaldehyde }\end{array}$ & aldehyde & $\bullet$ & & & & & $\bullet$ & $\bullet$ & $\bullet$ & \\
\hline 64 & beta-cyclocitral & aldehyde & & $\bullet$ & & $\bullet$ & & $\bullet$ & $\bullet$ & $\bullet$ & \\
\hline 65 & 7-methyl-pentadecane & alkane & & & & & & $\bullet$ & & & $\bullet$ \\
\hline 66 & sarcocapnidine & cyclic & & & & & $\bullet$ & $\bullet$ & & & $\bullet$ \\
\hline 67 & $\begin{array}{l}\text { 3-methylbut-3-enyl undecyl ester } \\
\text { fumaric acid }\end{array}$ & ester & $\bullet$ & & & & & & & & \\
\hline 68 & $\begin{array}{c}\text { 3-methylbut-3-enyl pentadecyl } \\
\text { ester fumaric acid }\end{array}$ & ester & & & & & & & & & \\
\hline 69 & octadecanoic acid & $\begin{array}{l}\text { carboxylic } \\
\text { acid }\end{array}$ & & & & $\bullet$ & & & & & \\
\hline 70 & 2-methylene cyclobutanone & alkane & & & & & & $\bullet$ & & & \\
\hline 71 & naphthalene & aromatic & & & $\bullet$ & & & & & & $\bullet$ \\
\hline 72 & isobutyl tetradecyl ether & ether & & & $\bullet$ & & & & & & \\
\hline 73 & isopropyl tetradecyl ether & ether & & & & $\bullet$ & & $\bullet$ & & & \\
\hline 74 & 2,4-dimethyl benzaldehyde & aldehyde & $\bullet$ & & & $\bullet$ & $\bullet$ & & $\bullet$ & $\bullet$ & \\
\hline 75 & benzaldehyde & aldehyde & & - & & & & $\bullet$ & & & \\
\hline 76 & 3,5-dimethyl benzaldehyde & aldehyde & & & & & & & $\bullet$ & $\bullet$ & \\
\hline 77 & geranyl acetone isomer 1 & ketone & $\bullet$ & & $\bullet$ & & & $\bullet$ & $\bullet$ & $\bullet$ & \\
\hline 78 & geranyl acetone isomer 2 & ketone & & $\bullet$ & & & $\bullet$ & & & & $\bullet$ \\
\hline 79 & benzyl alcohol & alcohol & & & & $\bullet$ & & & $\bullet$ & $\bullet$ & - \\
\hline 80 & cis-2-(1-pentenyl) furan & ether & & & & & & $\bullet$ & & & \\
\hline 81 & tricyclo $[4,4,0,0(2,8)]$ decane & alkane & $\bullet$ & & & & & & & & \\
\hline 82 & neophytadiene & diene & & & & & & & $\bullet$ & $\bullet$ & \\
\hline 83 & $\begin{array}{l}\text { 5-methylene } \\
\text { octahydro-1H-indene }\end{array}$ & alkane & & & & $\bullet$ & $\bullet$ & & & & \\
\hline 84 & bicyclo[3,3,1]non-2-en-9-one & ketone & & & & & & $\bullet$ & & & \\
\hline 85 & cyclohexanol & alcohol & & & & $\bullet$ & & & & & \\
\hline
\end{tabular}


Table A2. Cont.

\begin{tabular}{|c|c|c|c|c|c|c|c|c|c|c|c|}
\hline No & Compound * & Class & $\mathbf{A L}$ & $\mathrm{CH}$ & HU & LO_S & LO_N & LI & PI & TO & VE \\
\hline 86 & 3-buten-2-one & ketone & • & • & $\bullet$ & $\bullet$ & $\bullet$ & $\bullet$ & $\bullet$ & $\bullet$ & $\bullet$ \\
\hline 87 & $\beta$-ionone & ketone & $\bullet$ & & $\bullet$ & & & $\bullet$ & & & \\
\hline 88 & phenol & phenol & - & & & & & & & & \\
\hline 89 & [(2-methylpropyl) thio]-benzene & aromatic & & & & & & & & & $\bullet$ \\
\hline 90 & $\begin{array}{c}\text { 2-isopropyl-5,5- } \\
\text { dimethylcyclohex-2-enone }\end{array}$ & ketone & & & $\bullet$ & & & & & & \\
\hline 91 & glycerol 1,2-diacetate & ester & & & & & & & & & $\bullet$ \\
\hline 92 & 1-methylethyl benzoate & ester & & & & & & $\bullet$ & & & \\
\hline 93 & $\begin{array}{l}\text { 6,10,14-trimethyl-2- } \\
\text { pentadecanone }\end{array}$ & ketone & $\bullet$ & & & $\bullet$ & & & & & \\
\hline 94 & 6-methyl-2-tridecanone & ketone & & & & & $\bullet$ & & & & \\
\hline 95 & 6,10-dimethyl-2-undecanone & ketone & & $\bullet$ & & & & $\bullet$ & $\bullet$ & $\bullet$ & $\bullet$ \\
\hline 96 & 3-furanacetic acid & $\begin{array}{l}\text { carboxylic } \\
\text { acid }\end{array}$ & & & & & & & & & $\bullet$ \\
\hline 97 & $\begin{array}{l}\text { 4-(1-hydroxyallyl)-2- } \\
\text { methoxyphenol }\end{array}$ & phenol & & $\bullet$ & & $\bullet$ & $\bullet$ & & $\bullet$ & $\bullet$ & \\
\hline 98 & 2-propanone & ketone & $\bullet$ & & & & & & & & $\bullet$ \\
\hline 99 & 5-pentyl-1,3-benzenediol & alcohol & & & $\bullet$ & & & $\bullet$ & & & \\
\hline 100 & $\begin{array}{l}\text { 2-decyl dodecyl ester fumaric } \\
\text { acid }\end{array}$ & ester & $\bullet$ & & & & & & & & \\
\hline 101 & dihydro methyl jasmonate & ester & • & & & & & & $\bullet$ & $\bullet$ & \\
\hline 102 & 2,4-di-tert-butylphenol & phenol & $\bullet$ & $\bullet$ & $\bullet$ & & $\bullet$ & $\bullet$ & $\bullet$ & $\bullet$ & $\bullet$ \\
\hline 103 & 1,2-benzene dicarboxylic acid & $\begin{array}{l}\text { carboxylic } \\
\text { acid }\end{array}$ & $\bullet$ & & & & & $\bullet$ & $\bullet$ & $\bullet$ & $\bullet$ \\
\hline 104 & $\begin{array}{l}\text { 5,6,7,7a-tetrahydro-4,4,7a- } \\
\text { trimethyl-2(4h)-benzofuranone }\end{array}$ & terpene & $\bullet$ & & $\bullet$ & & & $\bullet$ & $\bullet$ & $\bullet$ & $\bullet$ \\
\hline 105 & mequinol & phenol & & & $\bullet$ & & & • & & & $\bullet$ \\
\hline 106 & butyl octyl phthalate & ester & $\bullet$ & & & & & & $\bullet$ & $\bullet$ & \\
\hline 107 & 2-methylbenza thiazole & thiazole & & $\bullet$ & & & & & & & \\
\hline
\end{tabular}

* For more details about samples see Table 1 ; ** Three replicates of each sample were analyzed.

\section{References}

1. Amarowicz, R.; Pegg, R.B.; Rahimi-Moghaddam, P.; Barl, B.; Weil, J.A. Free-radical scavenging capacity and antioxidant activity of selected plant species from the Canadian prairies. Food Chem. 2004, 84, 551-562. [CrossRef]

2. Asensio, E.; Vitales, D.; Pérez, I.; Peralba, L.; Viruel, J.; Montaner, C.; Vallès, J.; Garnatje, T.; Sales, E. Phenolic compounds content and genetic diversity at population level across the natural distribution range of bearberry (Arctostaphylos uva-ursi, ericaceae) in the iberian peninsula. Plants 2020, 9, 1250. [CrossRef]

3. Cui, T.; Nakamura, K.; Ma, L.; Li, J.Z.; Kayahara, H. Analyses of arbutin and chlorogenic acid, the major phenolic constituents in Oriental pear. J. Agric. Food Chem. 2005, 53, 3882-3887. [CrossRef]

4. Panusa, A.; Petrucci, R.; Marrosu, G.; Multari, G.; Gallo, F.R. UHPLC-PDA-ESI-TOF/MS metabolic profiling of Arctostaphylos pungens and Arctostaphylos uva-ursi. A comparative study of phenolic compounds from leaf methanolic extracts. Phytochemistry 2015, 115, 79-88. [CrossRef]

5. Dykes, G.A.; Amarowicz, R.; Pegg, R.B. Enhancement of nisin antibacterial activity by a bearberry (Arctostaphylos uva-ursi) leaf extract. Food Microbiol. 2003, 20, 211-216. [CrossRef]

6. Samoilova, Z.; Smirnova, G.; Muzyka, N.; Oktyabrsky, O. Medicinal plant extracts variously modulate susceptibility of Escherichia coli to different antibiotics. Microbiol. Res. 2014, 169, 307-313. [CrossRef]

7. Cybulska, P.; Thakur, S.D.; Foster, B.C.; Scott, I.M.; Leduc, R.I.; Arnason, J.T.; Dillon, J.A.R. Extracts of canadian first nations medicinal plants, used as natural products, inhibit neisseria gonorrhoeae isolates with different antibiotic resistance profiles. Sex. Transm. Dis. 2011, 38, 667-671. [CrossRef]

8. Jurica, K.; Gobin, I.; Kremer, D.; Čepo, D.V.; Grubešić, R.J.; Karačonji, I.B.; Kosalec, I. Arbutin and its metabolite hydroquinone as the main factors in the antimicrobial effect of strawberry tree (Arbutus unedo L.) leaves. J. Herb. Med. 2017, 8, 17-23. [CrossRef]

9. Naczk, M.; Pegg, R.B.; Amarowicz, R. Protein-precipitating capacity of bearberry-leaf (Arctostaphylos uva-ursi L. Sprengel) polyphenolics. Food Chem. 2011, 124, 1507-1513. [CrossRef]

10. Pavloviç, D.R.; Brankoviç, S.; Kovačeviç, N.; Kitiç, D.; Veljkoviç, S. Comparative study of spasmolytic properties, antioxidant activity and phenolic content of arbutus unedo from Montenegro and Greece. Phyther. Res. 2011, 25, 749-754. [CrossRef] 
11. Cobaleda-Velasco, M.; Alanis-Bañuelos, R.E.; Almaraz-Abarca, N.; Rojas-López, M.; González-Valdez, L.S.; Ávila-Reyes, J.A.; Rodrigo, S. Phenolic profiles and antioxidant properties of Physalis angulata L. as quality indicators. J. Pharm. Pharmacogn. Res. 2017, 5, 114-128.

12. Colon, M.; Nerin, C. Role of catechins in the antioxidant capacity of an active film containing green tea, green coffee, and grapefruit extracts. J. Agric. Food Chem. 2012, 60, 9842-9849. [CrossRef]

13. Huang, D.; Boxin, O.U.; Prior, R.L. The chemistry behind antioxidant capacity assays. J. Agric. Food Chem. 2005, 53, 1841-1856. [CrossRef]

14. Prior, R.L.; Wu, X.; Schaich, K. Standardized methods for the determination of antioxidant capacity and phenolics in foods and dietary supplements. J. Agric. Food Chem. 2005, 53, 4290-4302. [CrossRef]

15. Pyrzynska, K.; Pȩkal, A. Application of free radical diphenylpicrylhydrazyl (DPPH) to estimate the antioxidant capacity of food samples. Anal. Methods 2013, 5, 4288-4295. [CrossRef]

16. Carocho, M.; Morales, P.; Ferreira, I.C.F.R. Antioxidants: Reviewing the chemistry, food applications, legislation and role as preservatives. Trends Food Sci. Technol. 2018, 71, 107-120. [CrossRef]

17. Carocho, M.; Ferreira, I.C.F.R. A review on antioxidants, prooxidants and related controversy: Natural and synthetic compounds, screening and analysis methodologies and future perspectives. Food Chem. Toxicol. 2013, 51, 15-25. [CrossRef]

18. Altemimi, A.; Lakhssassi, N.; Baharlouei, A.; Watson, D.G.; Lightfoot, D.A. Phytochemicals: Extraction, isolation, and identification of bioactive compounds from plant extracts. Plants 2017, 6, 42. [CrossRef]

19. Yanishlieva-Maslarova, N.V.; Heinonen, I.M. 10-Sources of natural antioxidants: Vegetables, fruits, herbs, spices and teas. In Woodhead Publishing Series in Food Science, Technology and Nutrition; Pokorny, J., Yanishlieva, N., Gordon, M., Eds.; Woodhead Publishing: Sawston, UK, 2001; pp. 210-263. ISBN 978-1-85573-463-0.

20. Pokorný, J. Are natural antioxidants better-and safer-than synthetic antioxidants? Eur. J. Lipid Sci. Technol. 2007, 109, 629-642. [CrossRef]

21. Wrona, M.; Blasco, S.; Becerril, R.; Nerin, C.; Sales, E.; Asensio, E. Antioxidant and antimicrobial markers by UPLC ${ }^{\circledR}-E S I-Q-T O F-$ $\mathrm{MS}^{\mathrm{E}}$ of a new multilayer active packaging based on Arctostaphylos uva-ursi. Talanta 2019, 196, 498-509. [CrossRef]

22. Song, X.C.; Canellas, E.; Asensio, E.; Nerín, C. Predicting the antioxidant capacity and total phenolic content of bearberry leaves by data fusion of UV-Vis spectroscopy and UHPLC/Q-TOF-MS. Talanta 2020, 213, 120831. [CrossRef]

23. MR WATT SRL MR WATT Make Your Own Energy. Available online: https://www.mrwatt.eu/es/content/radiacion-solar-enespana (accessed on 28 February 2022).

24. Djebari, S.; Wrona, M.; Boudria, A.; Salafranca, J.; Nerin, C.; Bedjaoui, K.; Madani, K. Study of bioactive volatile compounds from different parts of Pistacia lentiscus L. extracts and their antioxidant and antibacterial activities for new active packaging application. Food Control 2021, 120, 107514. [CrossRef]

25. Gavril, G.L.; Wrona, M.; Bertella, A.; Świeca, M.; Râpă, M.; Salafranca, J.; Nerín, C. Influence of medicinal and aromatic plants into risk assessment of a new bioactive packaging based on polylactic acid (PLA). Food Chem. Toxicol. 2019, 132, 110662. [CrossRef] [PubMed]

26. Kaanin-Boudraa, G.; Brahmi, F.; Wrona, M.; Nerín, C.; Hadjal, S.; Madani, K.; Boulekbache-Makhlouf, L. Citrus $\times$ paradisi essential oil as a promising agent for margarine storage stability: Composition and antioxidant capacity. J. Food Process. Preserv. 2021, 45, e15374. [CrossRef]

27. Bentayeb, K.; Vera, P.; Rubio, C.; Nerin, C. Adaptation of the ORAC assay to the common laboratory equipment and subsequent application to antioxidant plastic films. Anal. Bioanal. Chem. 2009, 394, 903-910. [CrossRef]

28. Skowyra, M.; Falguera, V.; Azman, N.A.M.; Segovia, F.; Almajano, M.P. The effect of perilla frutescens extract on the oxidative stability of model food emulsions. Antioxidants 2014, 3, 38-54. [CrossRef]

29. Pascoal, A.; Quirantes-Piné, R.; Fernando, A.L.; Alexopoulou, E.; Segura-Carretero, A. Phenolic composition and antioxidant activity of kenaf leaves. Ind. Crop. Prod. 2015, 78, 116-123. [CrossRef]

30. Spadaccino, G.; Frabboni, L.; Petruzzi, F.; Disciglio, G.; Mentana, A.; Nardiello, D.; Quinto, M. Essential oil characterization of Prunus spinosa L., Salvia officinalis L., Eucalyptus globulus L., Melissa officinalis L. and Mentha x piperita L. by a volatolomic approach. J. Pharm. Biomed. Anal. 2021, 202, 114167. [CrossRef]

31. Cozzolino, R.; Pace, B.; Cefola, M.; Martignetti, A.; Stocchero, M.; Fratianni, F.; Nazzaro, F.; De Giulio, B. Assessment of volatile profile as potential marker of chilling injury of basil leaves during postharvest storage. Food Chem. 2016, 213, 361-368. [CrossRef]

32. Song, X.C.; Canellas, E.; Wrona, M.; Becerril, R.; Nerin, C. Comparison of two antioxidant packaging based on rosemary oleoresin and green tea extract coated on polyethylene terephthalate for extending the shelf life of minced pork meat. Food Packag. Shelf Life 2020, 26, 100588. [CrossRef]

33. Silva, C.L.; Câmara, J.S. Profiling of volatiles in the leaves of Lamiaceae species based on headspace solid phase microextraction and mass spectrometry. Food Res. Int. 2013, 51, 378-387. [CrossRef]

34. Linker, R.A.; Lee, D.H.; Ryan, S.; Van Dam, A.M.; Conrad, R.; Bista, P.; Zeng, W.; Hronowsky, X.; Buko, A.; Chollate, S.; et al. Fumaric acid esters exert neuroprotective effects in neuroinflammation via activation of the Nrf2 antioxidant pathway. Brain 2011, 134, 678-692. [CrossRef] [PubMed]

35. Denisov, E.T.; Afanas'Ev, I.B. Oxidation and Antioxidants in Organic Chemistry and Biology, 1st ed.; CRC Press: Boca Raton, FL, USA, 2005; ISBN 9781420030853. 
36. Wang, K.; Jin, P.; Cao, S.; Shang, H.; Yang, Z.; Zheng, Y. Methyl jasmonate reduces decay and enhances antioxidant capacity in Chinese bayberries. J. Agric. Food Chem. 2009, 57, 5809-5815. [CrossRef] [PubMed]

37. Francenia Santos-Sánchez, N.; Salas-Coronado, R.; Villanueva-Cañongo, C.; Hernández-Carlos, B. Antioxidant Compounds and Their Antioxidant Mechanism. In Antioxidants; Shalaby, E., Ed.; IntechOpen: London, UK, 2019; pp. 1-28.

38. Wang, S.; Meckling, K.A.; Marcone, M.F.; Kakuda, Y.; Tsao, R. Synergistic, additive, and antagonistic effects of food mixtures on total antioxidant capacities. J. Agric. Food Chem. 2011, 59, 960-968. [CrossRef] 